\title{
ВОЗНИКНОВЕНИЕ И СТАНОВЛЕНИЕ МИРОВОЙ ЮСТИЦИИ РОССИИ
}

\begin{abstract}
Аннотация: Статья содержит историко-правовой анализ возникновения и развития мировой юстиции России. Обосновывается оригинальный подход к понятию мировой юстиции, согласно которому в нее входят не только мировые суды, но и другие учреждения, осуществляющие функиии правосудия. Изучается законодательство и другие материаль о статусе судебных учреждений, действовавиих в России до судебной реформы 1864 года. Источниками для написания данной статьи стали научные труды дореволюционных и современных авторов по вопросам возникновения и становления мировой юстиции в России, а также архивные источники. Методологическую основу исследования составляют такие важнейшие принципы исторического познания, как научность, историзм, объективизм и комплексность научного анализа. Принцип историзма предусматривает изучение становления и развития института мировой юстиции в определенные исторические эпохи, характеризующиеся соответствующими общественно-политическими, идеологическими, социиально-экономическими условиями. Принцип научной объективности предполагает анализ заявленной темь на основе фактического документального материала, не входящего в противоречие с объективным отражением действительности. Сущуествование системы отечественных мировых учреждений, осуществляющих судопроизводство (суды общин, губные избы, земские, словесные и совестные суды, а также волостные суды и мировые посредники) позволяет сделать вывод о том, что мировая юстиция в дореволючиионной России представляет собой феномен, имеющий сугубо отечественные корни и специфику.
\end{abstract}

Ключевые слова: Мировая юстиция, мировой суд, судебные учреждения, ограниченная юрисдикция, судопроизводство, компетениия, статус, словесные суды, совестные суды, мировые посредники.

Abstract: This article contains a historical legal analysis of the origination and development of justice of the peace on Russia. The author substantiates the approach towards the concept of justice of the peace according to which, it is comprised of not only peace courts, but also other institutions carrying out the functions of justice. A research is made on the legislation and other materials on the status of judicial bodies active in Russia prior to the judicial reform of 1864 . The existence of Russian peace courts carrying out judicial functions (such as community courts, courts of conscience, etc.) allows us to conclude that justice of the peace in the pre-revolutionary Russia presents in itself a phenomenon that has strictly domestic roots and specificity.

Keywords: Status, competency, court procedure, limited jurisdiction, judicial bodies, peace court, justice of the peace, verbal courts, court of conscience, peace intermediaries.

отличие от законодательной и исполнительной ветвей государственной власти, структура и компетенция которых определяются посредством достаточно детального закрепления в конституционных текстах, статус судебной власти современной России раскрывается, в первую очередь, путем закрепления принципов ее осуществления (независимости, гласности, доступности и т.д.) ${ }^{1}$.

Конечно же, в Основном законе страны невозможно отразить все существенные положения о структурировании и осуществлении судебной власти, однако общий

\footnotetext{
${ }^{1}$ См.: Беляев В.П., Холодова Е.И. Мировая юстиция в России до начала XX века (историко-правовой очерк). Белгород, 2011. С. 5-6; Холодова Е.И. Становление и развитие мировой юстиции России в IX - начале XX вв.: историко-правовое исследование: автореф. дис. ... канд. юрид. наук. Тамбов, 2009.
}

характер конституционных норм порождает дискуссии не только теоретического, но и практического толка: о соотношении статуса и роли в политико-правовой системе государства федеральных и региональных судов (особенно в части структурирования конституционной юстиции); о пределах самостоятельности субъектов РФ в вопросах формирования «своих» судов и определения их компетенции, структуры, полномочий; о допустимости существования неограниченного количества видов специализированных судов, а также о роли мировой юстиции в российской судебной системе, ее «двойственной» природе и т.п.

Поэтому обоснованным представляется обращение в рамках настоящей статьи к вопросам становления и развития мировой юстиции в целях установления отечественных истоков ее возникновения, определения ее содержания и организационно-правовых 


\section{Право и политика 4 (184) 2015}

форм, а также выявления результатов и эффективности деятельности учреждений мировой юстиции вплоть до реформы 1864 года.

Наряду с изложенным, и это важно как для законодателя, так и для правоприменительной практики, есть необходимость предпринять попытку развести такие понятия, как «мировая юстиция» и «мировой суд», сущностное наполнение которых, по нашему мнению, не совпадает; мировую юстицию нельзя отождествлять только с системой мировых судов, что часто встречается в научных исследованиях и на практике, и вот почему.

Как известно, непосредственно термин «юстиция» в русском языке означает: а) правосудие, судопроизводство; б) совокупность государственных органов, занимающихся судопроизводством; в) систему судебных учреждений ${ }^{2}$, предлагается множество значений слов «мир» и «мировой», и слово «мир» созвучно слову «народ». Так, толковый словарь русского языка соотносит «мир» с человеческим обществом (например, мир - сельская община) $)^{3}$. Кроме этого, термин «мир» свидетельствует о согласии, отсутствии разногласий, вражды или ссоры; производное от него слово «мировой» означает - связанный с разрешением спора без суда или относящийся к разбору споров, касающихся главным образом мелких уголовных и гражданских дел; при этом производным является и применяемое словосочетание «мировой судья» ${ }^{4}$.

Исходя из изложенного, есть все основания полагать, что когда речь идет о мировой юстиции, то в содержание этого понятия следует включать деятельность всех учреждений (органов), осуществляющих функцию правосудия в форме ограниченной юрисдикции и в упрощенной процедуре, в том числе и путем примирения сторон (мировое соглашение). Но это - пока предварительный вывод, который, полагаем, найдет свое окончательное подтверждение при изучении российского опыта возникновения и становления мировой юстиции; предпримем такую попытку.

По справедливому мнению М.В. Титовой, историография истории юстиции России разработана слабо 5 . Отсюда существует и широкая палитра мнений

${ }^{2}$ Кузнецов С.А. Большой толковый словарь русского языка. СПб., 1998.

${ }^{3}$ Ожегов С.И., Шведова Н.Ю. Толковый словарь русского языка. М., 1993. С. 366.

${ }^{4}$ Современный толковый словарь русского языка. СПб., 2002. C. 351 .

${ }^{5}$ Титова М.В. Историография истории юстиции России // Наука и образование: хозяйство и экономика; предпринимательство; право и управление. 2010. № 3. С. 45. относительно истоков возникновения и становления российской мировой юстиции. При этом характерно то, что ученые, изучающие эту проблему, понятие мировой юстиции, как правило, увязывают с терминами «мирные судьи», «мировые судьи», считают их аналогичными, Поэтому, безусловно, права Е.А. Ванькина, когда пишет о затруднениях с определением сущности мировой юстиции, использованием понятия «мировой судья», «мировая юстиция» «мировой суд», которые чаще всего употребляются как синонимы ${ }^{6}$. В этом плане в качестве примера можно привести утверждение, к примеру, Т.К. Рябининой и Е.А. Грохотовой о том, что «в современном смысле мировая юстиция в России впервые (подчеркнуто авт.) была создана в ходе проведения судебно-правовой реформы в соответствии с Уставами 1864 г. $^{7}$

Однако, по нашему мнению, при установлении сущности мировой юстиции следует смотреть шире, брать за основу функциональную принадлежность того или иного органа (учреждения) относительно отправления правосудия (также в широком смысле этого слова) и не ставить знак равенства между понятиями мировой юстиции и мирового суда.

Надо сказать, что в историко-правовой литературе большинство авторов поддерживают точку зрения русского историка Г.А. Джаншиева о том, что первое упоминание о «мировых судьях» относится к 1826 году 8 . Но современный исследователь мировой юстиции С.В. Лонская считает, что «появление идей и предложений о введении мировых судей ... следовало бы отнести не к 1826 г., а на 60 лет ранее», хотя несколько и противоречит себе, когда в другом случае пишет, что одним из аналогов мировых судов были словесные суды, созданные еще в 1726 г. ${ }^{9}$

Можно продолжить обсуждение вопроса об истоках возникновения мировой юстиции России и привести мнения других авторов. Однако суть, полагаем, будет одна: преобладающей точкой зрения является такая, при которой между понятиями мировой юстиции и мирового суда ставится знак равенства; отсюда

\footnotetext{
${ }^{6}$ Ванькина Е.А. Об истории становления и развития мировой юстиции России // Социально-политические науки. 2011. № 1.С. 85.

${ }^{7}$ Tatyana K. Ryabinina, Helen A. Grokhotova The History of the Justice of the Peace Development in Russia as One of the Results of the Judicial Reform of 1864 // Bylye Gody. 2014. № 33 (3). P. 423.

8 Джаншиев Г.А. Из эпохи великих реформ. 4-е изд. М., 1893.

9 Лонская С.В. Мировая юстиция императорской России: идеи и аналоги (XVIII-первая половина XIX века) // Вестник Российского государственного университета им. И. Канта. 2009. Вып. 9. C. 25-33.
} 
делается вывод, что так называемая «классическая модель мировой юстиции» (кстати, многие авторы употребляют это понятие, но его определение в научных работах не встречается - авт.) возникает только с появлением мировых судов.

Позволим себе не согласиться с таким подходом и представить свой взгляд на историю возникновения мировой юстиции в России и ее сущность.

Отметим, что историко-правовые реалии в сфере судоустройства, сложившиеся в дореформенной (1864 г.) России, немаловажное место отводят мировым учреждениям, в той или иной мере осуществляющим судебную функцию при разрешении, как правило, малозначительных судебных тяжб.

При этом важно подчеркнуть, что мировой суд в России как государственно-правовой институт, приобрел свой юридический статус лишь тогда, когда ему были делегированы государственно-властные полномочия. Но «местный судья», рассматривающий дела о преступлениях, не представляющих большой общественной опасности, «в миру», максимально приближенный к народу, действующий по упрощенной процедуре и склоняющий стороны к примирению, существовал в нашем государстве и ранее.

К примеру, так называемые дела «малых исков» были предусмотрены еще нормами Русской Правды, и стороны имели право закончить дело миром. В статье 6 Краткой редакции (Академический список) Русской Правды устанавливалось: «Аще будеть нога цела или начьнеть храмати, тогда чада смирять» ${ }^{10}$. По нашему мнению, здесь усматривается зарождение мирового соглашения по «малым искам»- малозначительным категориям дел, не повлекших тяжких последствий («целая нога»).

Анализ норм Русской Правды дает возможность выявить в общих чертах правила примирительного разбирательства в судах общин, которые в IX-X веках были призваны улаживать конфликты между сторонами без участия государственных структур. По мнению М.Ф. ВладимирскогоБуданова, судебная власть общины возникает естественным образом как обязанность соседей помогать обиженному (призыв о помощи к соседям - крик - это термин, которым обозначается у некоторых народов исковое прошение $)^{11}$.

\footnotetext{
${ }^{10}$ Русская Правда // Российское законодательство Х-ХХ вв. / Под ред. О.И.Чистякова. М., 1984. Т. 1. С. 69.

${ }_{11}^{11}$ Владимирский-Буданов М.Ф. Обзор истории русского права. Ростов-на-Дону, 1995. С. 582.
}

В свою очередь, Ю.П. Титов рассматривает суд общины в качестве местного органа правосудия, «вершение» которого могло закончиться миром ${ }^{12}$.

Кроме этого, в древнерусском государстве действовал и суд братчин - мирских пиров, которым были подсудны дела о личных обидах, а также о побоях и драках, возникших на пиру13. Этот суд также был нацелен на примирение сторон.

Следует согласиться с коллективом авторов фундаментального исследования «Судебная власть в России. История. Документы», которые считают, что в древнерусском государстве отправление административных и судебных функций не было разграничено, и судебные полномочия сосредоточивались в органах управления всех уровней ${ }^{14}$.

В итоге, можно высказать мнение, что к этому времени в нашем государстве зарождается правовая традиция в области мировой юстиции как объективная потребность (социальный конфликт должен быть решен на территории общины - на миру - и отвечать ее интересам) и юридическая возможность урегулирования миром правового спора (определение процессуального порядка рассмотрения малозначительных категорий дел, который выражается в способности судов общин урегулировать спор примирением); начинают действовать мировые учреждения: суды общин и суды братчин.

Характерно то, что в более поздних источниках русского права (Судебниках 1497 и 1550 годов) мировому соглашению уделялось больше внимание, чем в древнерусских памятниках права; оно становилось объектом обложения судебной пошлиной. Так, норма статьи 4 Судебника 1497 г. содержала правило, согласно которому устанавливался размер пошлин при применении судебного поединка, в том числе и случае примирения сторон до его проведения ${ }^{15}$.

B XV-XVI веках в области гражданского оборота большое распространение получили земельные споры. Поскольку при их рассмотрении стороны зачастую не могли предоставить достаточное количество доказательств, а свидетели давали противоречивые показания, повсеместно возросло значение судебного поединка при невозможности выяснения истины иными

\footnotetext{
${ }^{12}$ Титов Ю.П. История государства и права. М., 1996. С. 39.

${ }^{13}$ Русская Правда // Памятники русского права. М., 1952. Вып. I. C. 81-85.

${ }^{14}$ Кутафин О.Е., Лебедев В.М., Семигин Г.Ю. Начала формирования судебной власти // Судебная власть в России. История. Документы. М., 2005.

${ }^{15}$ Судебник 1497 г. // Памятники русского права. Вып. III. М.,
} 1955. C. 339. 


\section{Право и политика $4(184) \cdot 2015$}

способами. Поэтому законодательное положение «а досудятца до поля да, став у поля, помирятца» вновь встречается в Судебнике 1550 года ${ }^{16}$.

Таким образом, в Судебниках 1497 и 1550 гг. фиксируется возможность урегулирования судебного спора мировым соглашением.

По мере усиления роли и активности государственной администрации в судебных «тяжбах» возрастает роль письменных документов. Поэтому уже Соборное Уложение 1649 года - источник, принятый в условиях новой формы политического устройства на этапе оформления сословной монархии, - требует для мирового соглашения обязательную письменную форму - мировую челобитную ${ }^{17}$.

Следовательно, использование в законодательном обороте терминов «в мале тяже», «смирять», «мировая челобитная», «став у поля, помирятца» подтверждает фактическое применение упрощенных судебных процедур, имеющих примирительный характер дает основание говорить о том, что возникновение мировой юстиции в истории русского государства происходит в достаточно давние времена.

Далее заметим, что судебные функции в русском государстве выполняли также наместники и волостели ${ }^{18}$. Они единолично рассматривали малозначительные категории гражданских и уголовных дел на подведомственной им территории. Как пишет М.Ф. Владимирский-Буданов, «наместники и волостели обладали или полной судебной властию, или неполной, чем и отличались наместники с судом боярским от наместников без суда боярского: первые могли решать высшие уголовные дела и некоторые дела о холопстве окончательно, вторые - нет» ${ }^{19}$.

Судебник 1550 года установил юрисдикцию земских и губных органов, отнеся к их ведению все категории дел для посадских людей и крестьян. Городским и сельским обществам в конце 40-х годов XVI века стали выдаваться губные грамоты, предоставлявшие право преследовать и наказывать «лихих людей». В ряде мест эту задачу выполняли специально избранные из мест-

\footnotetext{
${ }^{16}$ Судебник 1550 г. // Политическая история России: Хрестоматия: В 2 ч. Ч. І / Сост. В.И.Коваленко, А.Н. Медушевский, Е.Н. Мощелков. М., 1995. С. 83.

${ }^{17}$ Соборное Уложение 1649 г. // Полное собрание законов Российской Империи (далее - ПСЗ). Собрание 1. Т. 1 № 1. С. 121.

${ }^{18}$ Беляев И.Д. О суде наместничьем на Руси в старину // Юридический журнал. 1861. № 7. С. 289-304; № 8. С. 333-343; № 9. C. 388-396.

${ }_{19}^{19}$ Владимирский-Буданов М.Ф. Обзор истории русского права. M., 2005. C. 208.
}

ных жителей коллегии (губные избы). Одновременно учреждалась должность губного старосты, который в качестве судьи рассматривал уголовные дела. Хотя губные избы и не являлись чисто судебными органами, наличие у них права рассматривать малозначительные дела «миром» в определенной мере позволяет нам включить их в число учреждений мировой юстиции.

В становлении мировой юстиции в России свою роль сыграли и словесные суды, созданные в 1726 году 20. В компетенцию этих судов вначале входило рассмотрение в упрощенном порядке незначительных торговых споров купцов; они рассматривали дела устно и впоследствии превратились в суды по малозначительным гражданским делам (до 25 руб.) в соответствии с «Должностью словесных судов, по частям города утверждаемых» ${ }^{21}$ и Уставом благочиния 1782 г. $^{22}$

В первой четверти XVIII века процесс реализации преобразований в судебной области являлся весьма непоследовательным и противоречивым.

Как пишет К.С. Бельский, Петр I «запутал судопроизводство в России в такой гордиев узел», который его преемники распутывали после него почти пятьдесят лет, пока Екатериной II (1762-1796 гг.) не было издано в 1775 г. Учреждение для управлений губерний ${ }^{23}$, которым определялись два уровня судебных органов: а) губернский, который охватывал Палату уголовного суда, Палату гражданского суда и Верхний земский суд; б) уездный уровень, который включал уездный суд и нижний земский суд. Для суда над свободными крестьянами в уездах и губерниях были учреждены две судебные инстанции: нижняя расправа и верхняя расправа.

Изучение архивных материалов о деятельности нижнего земского суда нижней расправы) ${ }^{24}$ позволяет сделать вывод, что он создавался на местном уровне и по своему статусу может рассматриваться в качестве судебного учреждения мировой юстиции, так как в

\footnotetext{
20 Лонская С.В. Мировая юстиция императорской России: идеи и аналоги (XVIII-первая половина XIX века) // Вестник Российского государственного университета им. И. Канта. 2009. Вып. 9. С. 25-33.

${ }^{21}$ Именной указ от 2.04.1781 г. «О должности Словесных судов» // ПСЗ. Собрание 1. Т. 21. СПб., 1830. № 15146.

${ }^{22}$ ПСЗ. Собрание 1. Т. 21. № 15379.

${ }^{23}$ Учреждение для управления губерний Всероссийской империи 1775 г. // ПСЗ. Собрание 1. СПб., 1830. Т. 20. № 14392. С. 239-240. Документ состоял из двух частей, изданных в разные годы (в 1775 и в 1780 гг.), но включенных в Полное собрание законов Российской империи под одним номером.

${ }^{24}$ Александрович К. Киренская нижняя расправа в 1790 г. (по делам Расправа) // Труды Иркутской ученой архивной комиссии. 1916. Вып. 3. С. 389-393.
} 
его компетенцию входило: попечение об охранении тишины и спокойствия в уезде; приведение в исполнение распоряжений правительственных властей; дела по отбыванию различных повинностей; а также часть следственную, разбирательство по маловажным проступкам и решение незначительных исков 25 .

Научный интерес по заявленной теме представляет деятельность совестных судов, которые, с нашей точки зрения, также относятся к системе учреждений мировой юстиции (заметим, что термин «совестный» отождествлялся с понятием «спокойствие», «мир», «справедливость»). Совестные суды (введенные в 1792 году) были обязаны судить «не только по закону, но и по совести» ${ }^{26}$. Они учреждались в губерниях и состояли из представителей соответствующих сословий - председателя и двух заседателей (дворян - по дворянским делам, горожан - по делам горожан, крестьян - по крестьянским делам). Этот суд носил характер примирительного (рассматривал гражданские иски) и специализированного (разрешал дела о преступлениях малолетних, умалишенных).

В совестные суды поступали: а) дела, переданные сторонами на его рассмотрение, и б) уголовные дела, переданные из других судебных мест, в которых усматривались смягчающие обстоятельства (преступления безумных или малолетних, дела о колдовстве). По Своду законов 1857 г. юрисдикция совестного суда по делам торговым и исковым была ограничена мировым разрешением: а) дел, переданных на их рассмотрение сторонами по обоюдному согласию (факультативная юрисдикция), и б) дел между родителями и детьми по имущественным спорам (обязательная юрисдикция) и искам, вытекающим из обязательств сторон. Совестный суд объявлял «примирительное свое мнение» сторонам и в случае их несогласия представлял дело на окончательное разрешение в обычный суд.

Совестные суды характеризовались упрощенным порядком рассмотрения дел, ограниченной юрисдикцией и целью примирения сторон. По мнению И.А. Исаева, этот суд, рассматривавший малозначительные уголовные дела и гражданские споры, выступал в качестве третейского или мирового суда ${ }^{27}$.

Завершающий этап в развитии отечественных учреждений мировой юстиции связан с подготовкой Судебной реформы 1864 года. Появление ряда

\footnotetext{
${ }^{25}$ Устав благочиния 1782 г. // ПСЗ. Собрание 1. Т. 21. № 15379.

26 Учреждение для управления губерний Всероссийской империи от 7 ноября 1775 г. // ПСЗ. Собрание 1. Т.20. № 14392.

${ }^{27}$ Исаев И.А. История государства и права России. М., 2006. С. 334.
}

законопроектов, предусматривающих введение института мировых судей, во многом обусловливалось наличием объективных социально-экономических, политических и идеологических предпосылок: необходимостью создания судов для рассмотрения дел крестьян, которых предполагалось освободить от крепостной зависимости, низкой эффективностью судов, да политической ориентированностью на европейские государства (в Европе к тому времени были предприняты попытки создания общесословных судов и введения особых форм судопроизводства по рассмотрению малозначительных дел) ${ }^{28}$.

Разработчики проектов судебной реформы рассматривали мировых судей в качестве хранителей мира и судьями совести. Представление о мировом судье как о третейском судье смешивалось с понятием правосудия как чисто государственной деятельности. Отсюда противоречивость в понимании назначения и статуса мирового судьи, которая не была преодолена в ходе обсуждения проектов Судебных Уставов и перешла, таким образом, в их текст.

В порядке небольшого отступления обратим внимание на интересное совпадение: современный российский законодатель также не выработал единый подход к содержанию института мировой юстиции. Так, статья 4 Федерального конституционного закона «О судебной системе Российской Федерации» содержит положение, в соответствии с которым в единую судебную систему наряду с федеральными судами входят мировые судьи субъектов РФ. Налицо двойственность статуса мирового суда - он включен в общегосударственную судебную систему, процессуально подчинен федеральным судам (районным) и в то же время является судом субъекта Федерации. Вопросы формирования мировых судов относятся к компетенции законодательного (представительного) органа государственной власти субъекта Российской Федерации. Наше исследование позволяет утверждать, что сформированную в настоящее время систему мировых судей и учрежденный Судебными уставами 1864 г. институт мировых судей в Российской империи объединяет только название. Ведь возрождая мировой суд в современной России, законодатель ставил цель приблизить правосудие к населению, однако наиболее последовательно эта задача была решена дореволюционным законодательством. Конечно, цель возрождения мировой юстиции в современной России

${ }^{28}$ Коротких М.Г. Судебная реформа 1864 г. в России. Воронеж, 1994. C. 133. 


\section{Право и политика 4 (184) $\bullet 2015$}

- «переломить» негативные тенденции в судах общей юрисдикции как первый этап качественного изменения всей судебной системы была, в общем-то, достигнута, но правовой статус современного мирового суда как суда общей юрисдикции далек от его изначального предназначения. При этом следует иметь в виду, что мировые судьи в Российской империи в полной мере соответствовали главному смыслу учреждений мировой юстиции - максимальному приближению правосудия к населению.

Продолжая исследование, отметим, что работа по подготовке судебной реформы, начавшаяся в 1850-х гг., особенно интенсифицировалась после провозглашения крестьянской реформы. Как известно, 19 февраля 1861 года Александр II подписал Манифест об освобождении крестьян от крепостной зависимости ${ }^{29}$ и ряд законов об отмене крепостного права. В частности «Общее положение о крестьянах, вышедших из крепостной зависимости» предусматривало организацию крестьянского самоуправления (сельские волостные органы самоуправления). Главным органом в волости являлся волостной сход из выборных от сел - один выборный от десяти дворов ${ }^{30}$. Ежегодно волостной сход избирал волостной суд, который представлял собой выборный коллегиальный орган, состоящий из четырех-пятнадцати очередных судей, избираемых на годичный срок жителями той или иной волости.

В соответствии со статьей 95 Общего положения волостной суд «ведает... споры и тяжбы между крестьянами, так и дела по маловажным их проступкам». Статьи 96, 102 определяли его подведомственность. Так, волостные суды рассматривали малозначительные гражданские дела по личным и имущественным спорам, если сумма иска не превышала 100 рублей, и мелкие уголовные: драки, оскорбления, истребление имущества, за которые назначались наказания в виде штрафов, нескольких ударов розгами, административного ареста. Из подсудности волостных судов изымались некоторые дела (по категориям населения) - о проступках волостных и кантонных начальников. Кроме того, волостные суды не вправе были назначить телесные наказания престарелым лицам свыше 60 лет, духовным лицам, дворянам, офицерам и их детям, а также купцам ${ }^{31}$.

\footnotetext{
${ }^{29}$ ПСЗ. Собрание 2. СПб., 1865. Т. 36. № 36657.

${ }^{30}$ Общее положение о крестьянах, вышедших из крепостной зависимости. Ст. 71 // Российское законодательство Х-ХХ вв. Т. 7. M., 1991. C. 52.

${ }^{31}$ ПСЗ. Собрание 2. Т. 39. № 40156.
}

В решении дела принимали участие не менее трех судей или членов волостного суда. Апелляционные и кассационные жалобы на решения по делам не допускались, то есть волостной суд являлся органом так сказать «внутриобщинного», крестьянского правосудия.

Примечательно, что судьи волостных судов руководствовались, помимо закона, еще и обычаями, а также исходили из принципа целесообразности вынесения приговора. Согласно ст. 107 Общего положения о крестьянах, вышедших из крепостной зависимости, волостной суд решал дела «на основании заявленных в волостном правлении сделок и обязательств», а при отсутствии таковых «на основании местных обычаев и правил, принятых в крестьянском быту». Цель судопроизводства определялась предельно четко: при рассмотрении гражданского или уголовного дела судьи обязывались после выслушивания доводов тяжущихся сторон склонять их к примирению.

Считаем, что введение в законодательный оборот терминов «примирение», «мировая сделка» и упрощенной процедуры рассмотрения малозначительных категорий дел, безусловно, указывают на статус волостных судов как учреждений мировой юстиции.

Изучая процесс возникновения и становления мировой юстиции в России, уделим внимание и мировым посредникам. Так, в Манифесте 19 февраля 1861 года предусматривалось «для рассмотрения недоразумений и споров, могущих возникнуть при исполнении новых положений, назначить в уездах мировых посредников и образовать из них уездные мировые съезды» ${ }^{32}$. Наряду с этим, в Положении о губернских и уездных по крестьянским делам учреждениях предписывалось все жалобы и споры между помещиками и временнообязанными крестьянами рассматривать мировым посредникам ${ }^{33}$.

Остановимся подробнее на статусе мировых посредников, которые, полагаем, в дальнейшем стали своеобразной основой для учреждения и деятельности мировых судов. Мировой посредник назначался Сенатом по представлению губернатора на три года. Его полномочия распространялись на участок уезда, который образовывался из расчета населения - 10 тысяч душ мужского пола. В соответствии со статьями 23, 27, 30-31, 32 Положения о губернских

\footnotetext{
32 Манифест 19 февраля 1861 г. // Российское законодательство Х-XX вв. Т. 7. М., 1991. С. 29.

33 Положение о губернских и уездных по крестьянским делам учреждениях // ПСЗ. Собрание 2. Т. 36. № 36660.
} 
и уездных по крестьянским делам учреждениях в компетенцию мировых посредников входило: рассмотрение споров, жалоб и «недоразумений» между помещиками и временнообязанными крестьянами или дворовыми людьми, а также жалобы крестьян и обществ на решения волостных сходов, сельских и волостных должностных лиц; удостоверение разных актов, совершаемых между помещиками, временнообязанными крестьянами и дворовыми людьми; распорядительные действия по крестьянским делам (связанным с выкупом крестьянских земель и угодий, взысканием с крестьян недоимок по повинностям, утверждением в должности волостного старшины, избранием должностных лиц сельского и волостного управления, а также составление уставных грамот, регулирование повинностей и т.п.); судебно-полицейское разбирательство (наложение взысканий за совершение проступков должностными лицами сельского и волостного управлений; действия по назначению и смещению этих должностных лиц вследствие неисправного отправления повинностей; разрешение споров по найму в услужение; рассмотрение дел по аренде земель, по потравам полей, лугов и других угодий, по порубкам владельческих лесов) $)^{34}$.

Институт мировых посредников действовал до 1874 года и вызывал только положительные отклики, так как судебное разбирательство проходило быстро и упрощенно. С нашей точки зрения, есть все основания считать этот институт самостоятельным и полноценным элементом российской мировой юстиции.

Изучение историко-правового материала подводит к выводу о том, что функционирование мировых учреждений до Судебной реформы 1864 года способствовало последующему законодательному оформлению института мировых судей в качестве основной составляющей мировой юстиции, которая в условиях российской государственности имела определенное своеобразие.

В результате, по итогам проведенного исследования процесса возникновения и становления отечественных учреждений мировой юстиции можно сказать, что, безусловно, их возникновение в любой стране вызывается объективной необходимостью оперативного разрешения малозначительных социально-правовых конфликтов на определенной локальной территории авторитетными членами общины (ввиду их жизненного опыта, обширных знаний, личных нравственных качеств) с основной задачей

\footnotetext{
${ }^{34}$ Положение о губернских и уездных по крестьянским делам учреждениях // ПСЗ. Собрание 2. Т. 36. № 36660.
}

восстановления мира, спокойствия, справедливости и примирения конфликтующих сторон. Характерно, что мировые судебные учреждения дореволюционной России выделялись из общей судебной системы не просто как обычные местные суды ограниченной компетенции (рассматривающие малозначительные дела), но и как примирители спорящих сторон, судьи совести, хранители мира и спокойствия. Существование разветвленной системы отечественных мировых учреждений (суды общин, суды братчин, губные избы, ландрихтеры, земские, словесные и совестные суды, волостные суды, мировые посредники и их мировые съезды), дает основание для однозначного вывода о том, что мировая юстиция в России представляет собой феномен, имеющий сугубо отечественные корни и специфику. Исходя из историко-правового опыта России, полагаем, что в содержание мировой юстиции входят два основополагающих взаимосвязанных момента: во-первых, приближенность правосудия к населению; во-вторых, осуществление судопроизводства по особым, упрощенным правилам.

В связи с изложенным можно только сожалеть о том, что в России в настоящее время как в уголовно-процессуальном, так и в гражданском процессуальном законодательстве недостаточно полно представлены нормы, определяющие специфику производства у мирового судьи. Вот как справедливо по этому поводу пишет С.В. Лонская: «Однако мы недооцениваем то, что исторический (или зарубежный) опыт должен быть осмыслен и использован с учетом сегодняшнего, да и завтрашнего дня. Отсюда - и непроработанность изначальной концепции мировой юстиции в РФ, ее неопределенность в настоящее время» ${ }^{35}$.

Формулируя заключительное положение по настоящему исследованию, подчеркнем, что с момента образования древнерусского государства (с принятием Русской Правды) формируется отечественная традиция в области мировой юстиции, которая заключалась в компетенции местных судебных и иных органов (учреждений) рассматривать малозначительные категории гражданских и уголовных дел по упрощенной процедуре, получившая свое развитие и структурное оформление в виде различного рода учреждений мировой юстиции, возникновение и становление которой не следует увязывать исключительно с учреждением мирового суда в 1864 году.

\footnotetext{
35 Лонская С.В. История мировой юстиции в России в ракурсе конкуренции концептуальных подходов // Вестник Омского университета. Серия «Право». 2012. № 3 (32). С. 19-24.
} 


\section{Право и политика 4 (184) • 2015}

\section{Библиография:}

1. Tatyana K. Ryabinina, Helen A. Grokhotova The History of the Justice of the Peace Development in Russia as One of the Results of the Judicial Reform of 1864 // Bylye Gody. 2014. № 33 (3).

2. Беляев В.П., Холодова Е.И. Мировая юстиция в России до начала ХХ века (историко-правовой очерк). Белгород, 2011.

3. Беляев И.Д. О суде наместничьем на Руси в старину // Юридический журнал. 1861. № 7-9.

4. Ванькина Е.А. Об истории становления и развития мировой юстиции России // Социально-политические науки. 2011 . № 1.

5. Владимирский-Буданов М.Ф. Обзор истории русского права. Ростов-на-Дону, 1995.

6. Джаншиев Г.А. Из эпохи великих реформ. 4-е изд. М., 1893.

7. Исаев И.А. История государства и права России. М., 2006.

8. Коротких М.Г. Судебная реформа 1864 г. в России. Воронеж, 1994.

9. Кутафин О.Е., Лебедев В.М., Семигин Г.Ю. Начала формирования судебной власти // Судебная власть в России. История. Документы. М., 2005.

10. Лонская С.В. История мировой юстиции в России в ракурсе конкуренции концептуальных подходов // Вестник Омского университета. Серия «Право». 2012. № 3 (32).

11. Лонская С.В. Мировая юстиция императорской России: идеи и аналоги (XVIII-первая половина XIX века) // Вестник Российского государственного университета им. И. Канта. 2009. Вып. 9. С. 25-33.

12. Титов Ю.П. История государства и права. М., 1996.

13. Титова М.В. Историография истории юстиции России // Наука и образование: хозяйство и экономика; предпринимательство; право и управление. 2010. № 3.

14. Холодова Е.И. Становление и развитие мировой юстиции России в IX-начале XX вв.: историко-правовое исследование: автореф. дис. ... канд. юрид. наук. Тамбов, 2009.

15. Береговая Е.В. Мировая юстиция в российской политической системе (по материалам социологического исследования) // Политика и Общество. - 2013. - 8. - C. 988 - 993. DOI: 10.7256/1812-8696.2013.8.9086.

16. Береговая Е.В. Проблема двойственности статуса мировых судей в России // Политика и Общество. - 2014. - 5. - С. 486 - 493. DOI: 10.7256/1812-8696.2014.5.9779.

\section{References (transliterated):}

1. Tatyana K. Ryabinina, Helen A. Grokhotova The History of the Justice of the Peace Development in Russia as One of the Results of the Judicial Reform of 1864 // Bylye Gody. 2014. № 33 (3).

2. Belyaev V.P., Kholodova E.I. Mirovaya yustitsiya v Rossii do nachala KhKh veka (istoriko-pravovoi ocherk). Belgorod, 2011.

3. Belyaev I.D. O sude namestnich’em na Rusi v starinu // Yuridicheskii zhurnal. 1861. № 7-9.

4. Van’kina E.A. Ob istorii stanovleniya i razvitiya mirovoi yustitsii Rossii // Sotsial'no-politicheskie nauki. 2011 . № 1.

5. Vladimirskii-Budanov M.F. Obzor istorii russkogo prava. Rostov-na-Donu, 1995.

6. Dzhanshiev G.A. Iz epokhi velikikh reform. 4-e izd. M., 1893.

7. Isaev I.A. Istoriya gosudarstva i prava Rossii. M., 2006.

8. Korotkikh M.G. Sudebnaya reforma 1864 g. v Rossii. Voronezh, 1994.

9. Kutafin O.E., Lebedev V.M., Semigin G.Yu. Nachala formirovaniya sudebnoi vlasti // Sudebnaya vlast' v Rossii. Istoriya. Dokumenty. M., 2005.

10. Lonskaya S.V. Istoriya mirovoi yustitsii v Rossii v rakurse konkurentsii kontseptual'nykh podkhodov // Vestnik Omskogo universiteta. Seriya «Pravo». 2012. № 3 (32).

11. Lonskaya S.V. Mirovaya yustitsiya imperatorskoi Rossii: idei i analogi (XVIII-pervaya polovina XIX veka) // Vestnik Rossiiskogo gosudarstvennogo universiteta im. I. Kanta. 2009. Vyp. 9. S. 25-33.

12. Titov Yu.P. Istoriya gosudarstva i prava. M., 1996.

13. Titova M.V. Istoriografiya istorii yustitsii Rossii // Nauka i obrazovanie: khozyaistvo i ekonomika; predprinimatel'stvo; pravo i upravlenie. 2010. № 3 .

14. Kholodova E.I. Stanovlenie i razvitie mirovoi yustitsii Rossii v IX-nachale XX vv.: istoriko-pravovoe issledovanie: avtoref. dis. ... kand. yurid. nauk. Tambov, 2009.

15. Beregovaya E.V. Mirovaya yustitsiya v rossiiskoi politicheskoi sisteme (po materialam sotsiologicheskogo issledovaniya) // Politika i Obshchestvo. - 2013. - 8. - C. 988 - 993. DOI: 10.7256/1812-8696.2013.8.9086.

16. Beregovaya E.V. Problema dvoistvennosti statusa mirovykh sudei v Rossii // Politika i Obshchestvo. - 2014. - 5. - C. 486 - 493. DOI: $10.7256 / 1812-8696.2014 .5 .9779$. 